\title{
Observations on the Cave-Associated Beetles (Coleoptera) of Nova Scotia, Canada
}

\author{
Max Moseley ${ }^{1}$
}

\begin{abstract}
:
Moseley M. 2009. Observations on the Cave-Associated Beetles (Coleoptera) of Nova Scotia, Canada. International Journal of Speleology, 38(2), 163-172. Bologna (Italy). ISSN 0392-6672.

The cave-associated invertebrates of Nova Scotia constitute a fauna at a very early stage of post-glacial recolonization. The Coleoptera are characterized by low species diversity. A staphylinid Quedius spelaeus spelaeus, a predator, is the only regularly encountered beetle. Ten other terrestrial species registered from cave environments in the province are collected infrequently. They include three other rove-beetles: Brathinus nitidus, Gennadota canadensis and Atheta annexa. The latter two together with Catops gratiosus (Leiodidae) constitute a small group of cave-associated beetles found in decompositional situations. Quedius s. spelaeus and a small suite of other guanophiles live in accumulations of porcupine dung: Agolinus leopardus (Scarabaeidae), Corticaria serrata (Latrididae), and Acrotrichis castanea (Ptilidae). Two adventive weevils Otiorhynchus ligneus and Barypeithes pellucidus (Curculionidae) collected in shallow cave passages are seasonal transients; Dermestes lardarius (Dermestidae), recorded from one cave, was probably an accidental (stray). Five of the terrestrial beetles are adventive Palaearctic species. Aquatic beetles are collected infrequently. Four taxa have been recorded: Agabus larsoni (Dytiscidae) may be habitual in regional caves; another Agabus sp. (probably semivittatus), Dytiscus sp. (Dytiscidae), and Crenitis digesta (Hydrophilidae) are accidentals. The distribution and ecology of recorded species are discussed, and attention is drawn to the association of beetles found in a Nova Scotia "ice cave".
\end{abstract}

Keywords: cave fauna, Coleoptera, beetles, Nova Scotia, Canada

Received 17 March 2009; Revised 24 April 2009; Accepted 20 May 2009

\section{INTRODUCTION}

Although they are still in the main poorly described, the invertebrate communities inhabiting caves in the formerly glaciated northern regions of North America are of considerable interest. They are composed almost entirely of species in a dynamic and early phase of post-glacial repopulation and thus may offer opportunities to gain insights into the little understood earliest stages of colonization of subterranean habitats. In Nova Scotia there is evidence that postglacial recolonization of cave habitats by some species was relatively delayed by zoogeographical barriers and is at an earlier stage than that of neighbouring geographical regions (Moseley, 2007a).

Coleoptera are of particular interest in cave biology. As a group, beetles are among the most important cavernicolous insects: Gibert \& Deharveng (2002) estimated that the Order contains $73 \%$ of the described 'troglobitic' terrestrial insects, and unlike many other organisms found in caves the taxonomy, distribution, and biology of beetles are well investigated. The genus Quedius and some other lines display different progressive stages of behavioural, physiological

1. 90/9 Soi 49, Saiburi Road, Amphoe Muang, Songkhla

90000, THAILAND. maxmoseley@hotmail.com and morphological adaptation to subterranean life (Moseley et al., 2006; Moldova \& Rajka, 2007).

Knowledge of the composition and ecology of the beetle fauna of Nova Scotia caves has accumulated slowly as a result of general invertebrate surveys made from time to time since the 1960s. Calder and Bleakney (1967) listed three beetles from a small gypsum cave used as a porcupine den: Quedius spelaeus spelaeus, Brathinus nitidus (Staphylinidae) and Aphodius leopardus [now known as Agolinus leopardus] (Scarabaeidae). The next four decades produced new occurrence records of the two staphylinids, the addition of five further terrestrial beetles to the provincial checklist and the first records of aquatic species (Moseley, 1998, 2007a; Majka et al., 2006; Moseley et al., 2006). Subsequent fieldwork has now increased the total to 15 (4 aquatic and 11 terrestrial) taxa, and added further occurrence records of previously listed species.

Moseley et al. (2006) gave some details of the life history of $Q$. s. spelaeus, noted its role as an important predator in subterranean communities, and conjectured that the provincial population may have immigrated from late-glacial offshore refugia, while Majka et al. (2006) briefly discussed the distribution and ecology of $G$. canadensis in Nova Scotia, based mainly on new surface records. Except for the preliminary check-list and summary of 
records that were provided by Moseley (2007a) almost nothing is known about other beetle species utilizing subterranean habitats in the province.

This paper describes and discusses the composition, geographical distributions and ecology of the cave-associated Coleoptera of Nova Scotia. It is a contribution to knowledge of the poorly investigated subterranean fauna of glaciated North America.

\section{METHODS}

Beetles were collected from caves and abandoned hardrock mines in mainland Nova Scotia and Cape Breton Island intermittently between 1969 and 2007. Invertebrates were sampled from 17 sites mainly by hand, from bulk substrate samples, and in unbaited pitfall traps: set baits and baited traps were used sparingly. Those sites where beetles were collected are shown in Fig. 1. Further details and comprehensive background information including a full list of collecting sites, ecological notes, details of associated fauna, and a bibliography were provided by Moseley (2007a).

All specimens were collected by M. Moseley except where otherwise indicated. Voucher specimens are deposited in the Natural History collections of the Nova Scotia Museum (Halifax, Canada) and/or retained by the identifying taxonomist.
Threshold (th.), deep threshold (d.th.), and dark zone (d.z.) are as defined in Moseley (2007a). Use of the illdefined terms troglobite, troglophile and trogloxene has been avoided as far as possible: where they appear in citations from another author they are to be understood in the sense intended by the writer concerned.

\section{RESULTS}

Fifteen beetle taxa have been collected from cave environments in Nova Scotia in the families Dytiscidae (3), Hydrophilidae (1), Ptilidae (1), Leiodidae (1), Staphylinidae (4), Scarabaeidae (1), Dermestidae (1), Latrididae (1), and Curculionidae (2). Individual accounts of all taxa follow.

\section{Dytiscidae}

Agabus larsoni Fery \& Nilsson 1993

Nova Scotia cave records: Hayes Cave, 3.VIII.1997, d.z. in large pond (1 adult, det. Y. Alarie).

Geographical distribution and occurrence: known from eastern Canada and northern New England, where it is mainly found in small cold woodland pools (Larson et al., 2000).

Cave ecology: This beetle has also been collected in a limestone stream cave in Kings County, New

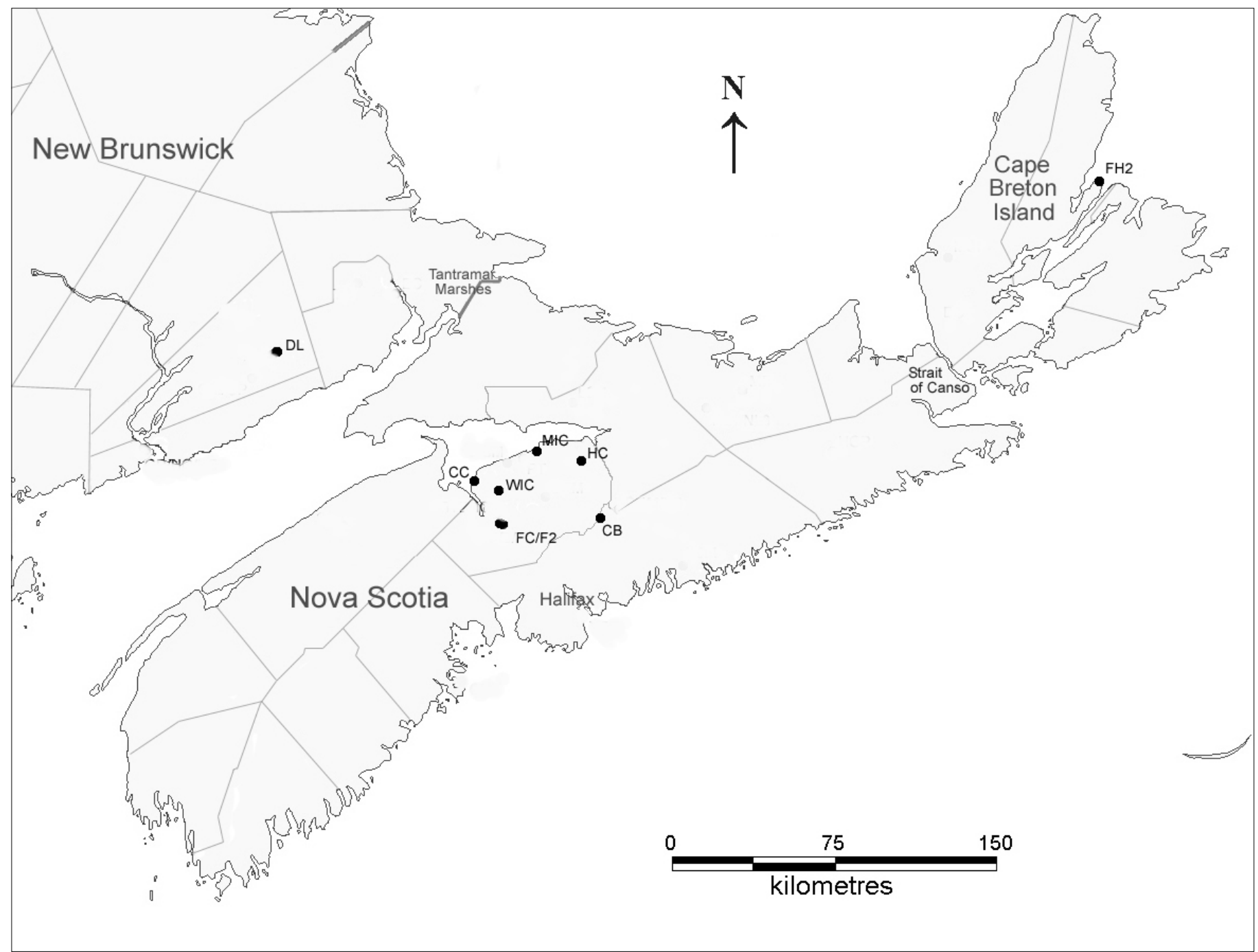

Fig. 1. Outline map to show location of collecting sites $[\mathrm{CB}=$ Cave-of-the-Bats; $\mathrm{CC}=$ Cheverie Cave/mine; $\mathrm{DL}=\mathrm{Dalling}$ 's Cave; $\mathrm{FC}=\mathrm{Frenchman}$ 's Cave; F2 = Frenchman's II; FH2 = Fairy Hole II; HC = Hayes Cave; MIC = Minasville Ice Cave; WIC = Woodville Ice Cave]. 
Brunswick, Canada, where there appeared to be a thriving population (Dalling's Cave, 24.VIII.2005, common, th.-d.z. and also in stream outside cave, under stones [det. C. G. Majka]). It is probably habitual within suitable caves in eastern Canada.

Agabus sp. prob. semivittatus LeConte 1852

NS cave records: Cave-of-the-Bats, 28.VI.1995, d.z. in pool associated with plant flood debris (1 adult, det. Y. Alarie).

Geographical distribution and occurrence: Agabus semivittatus is a widespread epigean species that normally occurs in streams, seeps and springfed pools (Larson et al. 2000) but, with the exception of the above cave record, is not reported from Nova Scotia (C. G. Majka, pers. comm.). The specimen was identified by a recognised specialist but cannot now be located for verification and the taxon is treated here as Agabus sp. prob. semivittatus.

Cave ecology: Accidental.

\section{Dytiscus sp.}

NS cave records: Cave-of-the-Bats, 28.VI.1995,d.z. in stream associated with plant flood debris (one $3 \mathrm{rd}$ instar larva).

Cave ecology: Accidental.

\section{Hydrophilidae}

Crenitis digesta (LeConte, 1855)

NS cave records: Frenchman's II (cave), 14.X. 1996,d. th. (1 adult, det. S.B. Peck ).

Geographical distribution and occurrence: Widespread in eastern North America (S. Peck, pers. comm.).

Cave ecology: Accidental.

\section{Ptilidae}

Acrotrichis castanea (Matthews, 1877) [Fig. 2A]

NS cave records: Frenchman's II (cave), 5.X.1997 and 18.X.1997, abundant d.th. to d.z. in 'moderately decomposed' (pH 6.5) porcupine dung (det. M. Sörensson); 18.X.1997, d.th. in wet plant debris (1).

Geographical distribution and occurrence: a widely distributed Nearctic species (in Canada from British Columbia to Nova Scotia) (Majka \& Sörensson, 2007).

Cave ecology: This guanophile species was abundant in Frenchman's II and has also been collected from a cave in Illinois (Sörensson, 2003) suggesting that it may be more common in such habitats than presently known. Ptilids are probably often overlooked in cave collections due to their small size and secretive habits.

\section{Leiodidae: Cholevinae}

\section{Catops gratiosus (Blanchard, 1915)}

NS cave records: Woodville Ice Cave, 9.IX.2007, d.th. (broken rock and leaf litter) in unbaited pitfall trap $(1 \hat{\jmath}, 1$, , det. C. G. Majka); 22.IX.2007, d.th. in unbaited pitfall (1우 det. C. G. Majka).

Geographical distribution and occurrence: Catops gratiosus is an infrequently collected species reported from central Nova Scotia to northern Cape Breton (Majka \& Langor, 2008). It has not otherwise been recorded in Atlantic Canada and the nearest records to the region are from southern Maine, Ontario, and Quebec (Peck \& Cook, 2002)

Cave ecology: Peck \& Cook (2002) recorded the species from 62 caves in Alabama, Georgia, Illinois, Indiana, Iowa, Kentucky, Maryland, Massachusetts, New York, Ohio, Pennsylvania, Tennessee, Virginia, and West Virginia. Although it has a behavioural affinity for caves, it exhibits no apparent morphological specializations for subterranean life. While most specimens collected in western and northeastern North America are from deciduous and coniferous forests, most of the collections at lower elevations in the southeastern USA are from caves (usually near the entrances) which it is thought may serve as cool and moist refugia in warmer and drier low elevation regions (Peck \& Cook, 2002). However cave records from Ontario (Peck, 1988) and now from Nova Scotia show that it does utilize caves in the north, suggesting that it is probably present in such habitats throughout its geographical range. Beetles have been taken in forests on carrion, decaying fungi, and mammal dung and in caves on dead mice and bats but not on bat guano (Peck \& Cook, 2002).

\section{Staphylinidae: Omaliinae}

\section{Brathinus nitidus LeConte, 1852}

NS cave records: Frenchman's Cave, no details (1, det. T. Barr) (Calder \& Bleakney, 1967); Fairy Hole II, 24.X.1971, on deposit of fish bones in d.z. (1, det. J. M. Campbell) (Moseley, 2007a).

Geographical distribution and occurrence: Brathinus nitidus is a Nearctic species distributed from Newfoundland and Nova Scotia westwards to the Lake Superior region and south along the Appalachians to northern Alabama (Peck, 1975). It is associated with shaded cool wet habitats with most of the more southerly records being from caves (Peck, 1975). The Canadian National Collection has 88 examples all collected 9.VII.1984 - 25.IX.1984 in Cape Breton from litter, moss, dead logs, mushrooms etc., often along streams or near waterfalls (A. Davies, pers. comm.). The Frenchman's Cave record is the sole mainland Nova Scotia report of the species. Careful searching of both the cave and its immediate vicinity in 2007 failed to secure additional specimens.

Cave ecology: Because it is often encountered underground Peck \& Thayer (2003) regarded this beetle as a 'troglophile'. Peck (1975) stated that it survives quite well in the dark zone as well as the threshold and also noted that a probable larva had been reported from a cave in Tennessee but was unable to find any larvae in caves himself. In the absence of proof of an ability to breed in them, it is possible that only adults in search of cool humid conditions enter 
caves.

Staphylinidae: Staphylininae

Quedius (Microsaurus) spelaeus spelaeus Horn, 1871 [Figs. 2B; 3A,D]

NS cave records: Cheverie Cave/mine, 21.VII.2007, running across mud floor in d.z. (1 adult); 5.VII.2007, d.z. under pork liver bait (1 late-instar larva); 5.VII.2007, d.z. under rocks on loamy floor (2 adults); 15.VIII.2007, d.z. in worm casts (1 larva). Frenchman's Cave, 19.VIII.2007, d.th. in porcupine dung (1 larva, parasitized by a wasp [Hymenoptera: Proctotrupidae]; 19.VIII.2007, d.th. under stone ( $\hat{0}+$ pair, collected live and observed mating in culture). Woodville Ice Cave, 9.IX.2007, d.th. in unbaited pitfall placed in scree (1 adult). For records prior to 2007 see Moseley et al. (2006).

Geographical distribution and occurrence: The geographical distribution of this Nearctic rovebeetle was discussed by Moseley et al. (2006). The Nova Scotia population appears to be disjunct and may have immigrated from late-Pleistocene offshore

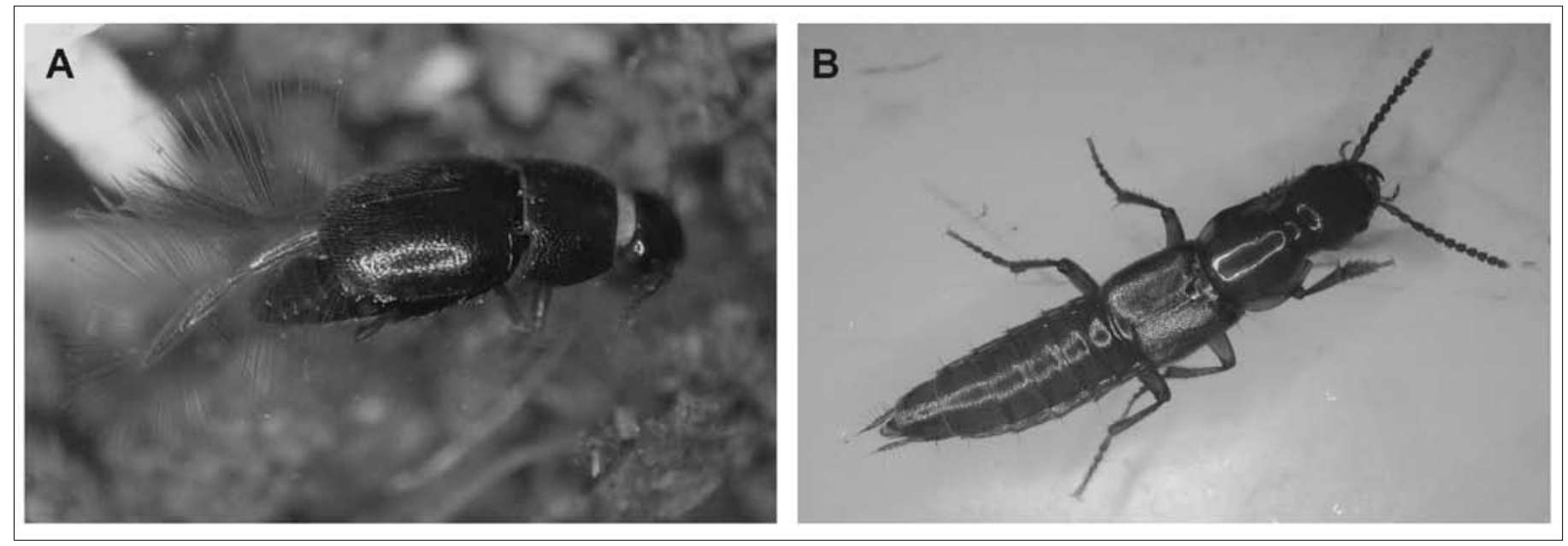

Fig. 2.: A: Acrotrichis castanea, preserved adult [Frenchman's II, 5.X.1997] (photo: C. Majka). B: Quedius s. spelaeus, live adult [Cheverie Cave/ mine, 21.VII.2007] (photo: author).

A

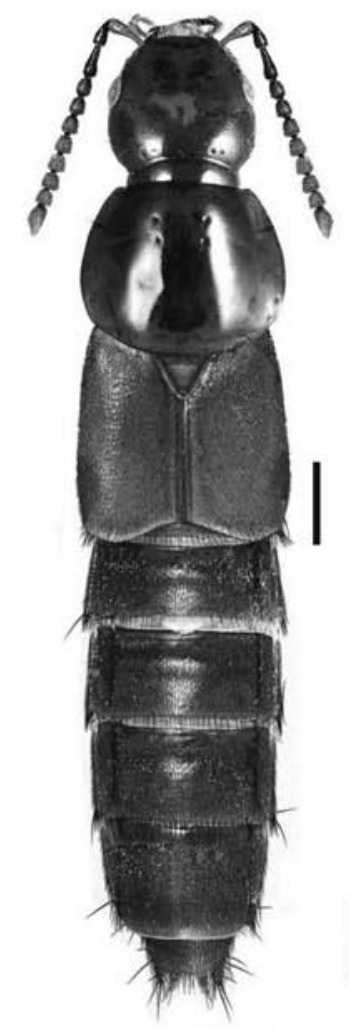

B

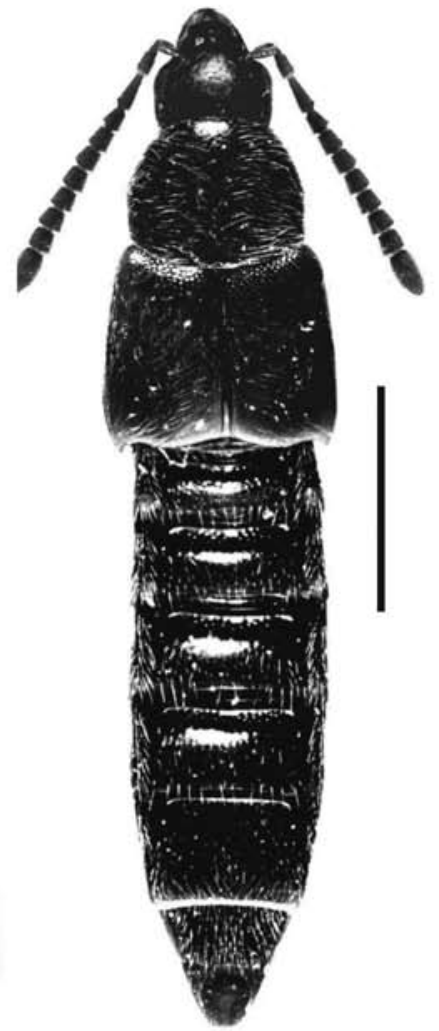

C

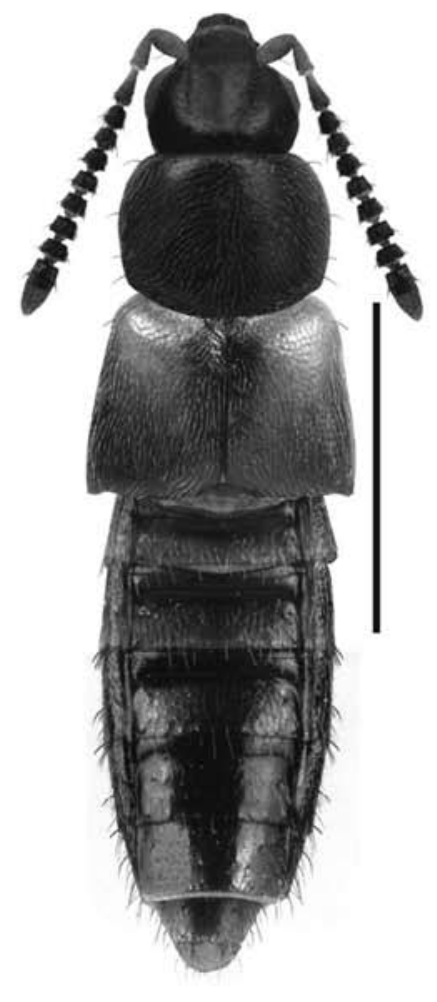

D

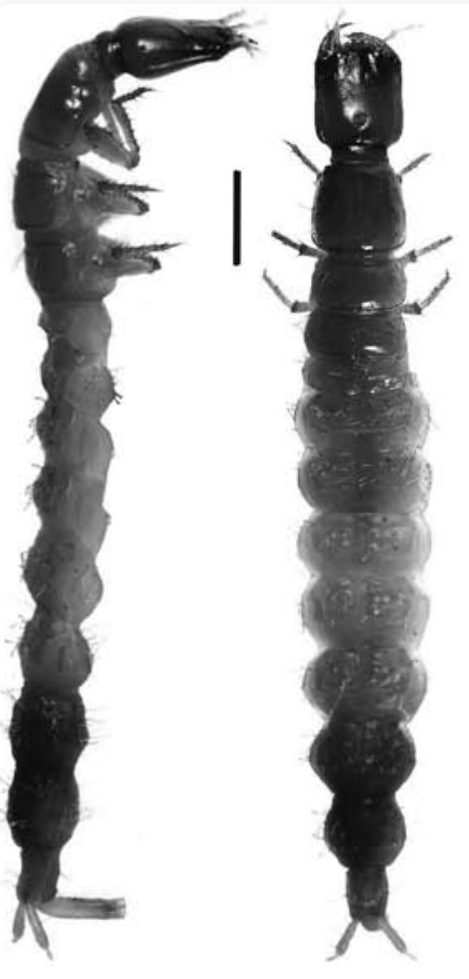

Fig. 3. Illustrations of Staphylinidae (photos: G. Pelletier) (3B: after Majka et al., 2006). A: Quedius s. spelaeus, adult. B: Gennadota canadensis, adult. C: Atheta annexa, adult. D: Q. s. spelaeus, late-instar larva [All scale lines $=1 \mathrm{~mm}$ ]. 
Atlantic refugia (Moseley et al., 2006).

Cave ecology: Quedius s. spelaeus is a subterranean species that, with the exception of examples from animal burrows in western North America, has never been collected outside caves (Smetana, 1971). The Nova Scotia population may be restricted to subterranean habitats. Adults and larvae are top predators in cave invertebrate communities (Moseley et al., 2006). It is by far the most frequently collected beetle in Nova Scotia caves, and probably present in all or almost all such underground sites throughout the province. It is found both in the threshold near entrances and in the dark zone, usually associated with porcupine dung but also with other organic substrates (Fig. 4). Most adults have been collected as single individuals from under stones, but they are mobile and have also been observed running across a cave floor in the open and have been taken in unbaited pitfall traps. Male-female pairs are sometimes found under stones, and have been observed mating in culture.

Adults held in culture become agitated even in subdued light and are observed to attempt where possible to burrow into porcupine dung or other unconsolidated substrate. However, when offered stones placed on the surface they often preferentially locate under these, even in the absence of ambient light, rather than burrowing. This is in line with field observations.

Larvae are found within deposits of dung or other suitable organic materials such as worm casts, although the capture of one late-instar larva under recently set pork liver bait implies that they do on occasion move around. Late instar larvae (length 7.0$14.4 \mathrm{~mm}$. Mean $10.6 \mathrm{~mm}$ ) are frequently seen and have been collected in June, July and October but smaller larvae have never been found despite collecting over many years including Tullgren extractions of bulk dung samples.

A late-instar Q. s. spelaeus larva collected from a cave threshold proved to be parasitized by a proctotrupid wasp (Exallonyx sp?). Although it remained undersized (length $=8 \mathrm{~mm}$ ), the reared larva behaved in the same way as healthy larvae (Moseley et. al., 2006) excavating

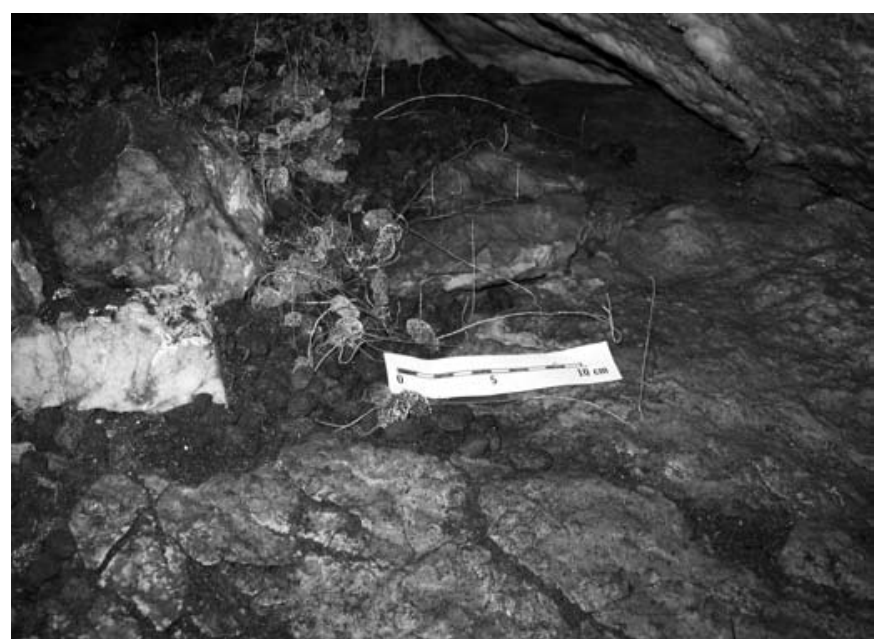

Fig. 4. Broken rock embedded in deposits of partly-decomposed porcupine dung in Frenchman's Cave, Hants County, Nova Scotia. This is typical habitat for Q. s. spelaeus (photo: author). a cavity in dung adjacent to the wall of the culture jar and pupating therein before emergence of the wasp.

\section{Staphylinidae: Aleocharinae}

Gennadota canadensis Casey, 1906 [Fig. 3B]

NS cave records: Woodville Ice Cave, winter 19971998,d.th. in molasses-baited pitfall (1 adult, det. J. Klimaszewski; 1 presumptive larva associated with adult) (Majka et al., 2006).

Distribution and occurrence: This is a rarelycollected Nearctic species known only from Pennsylvania, Quebec, and Nova Scotia. Half of the known specimens have been collected in caves, the balance in various epigean decomposition situations (Majka et al., 2006)

Cave ecology: Although the few existing collection records do indicate that this beetle has some propensity for entering caves it is not known if it can establish permanent breeding populations underground.

Atheta annexa Casey, 1910 [Fig. 3C]

NS cave records: Woodville Ice Cave, 3.VIII.2007, d.th. in sample of leaf litter and soil (1 adult, det. J. Klimaszewski); 9.IX.2007, d.th. in unbaited pitfall (1 adult, det. M. Moseley).

Geographical distribution and occurrence: This Nearctic aleocharine is distributed from Iowa, Illinois, and Indiana, south to Florida and Alabama, east to Virginia, and west to Missouri (Klimaszewski \& Peck, 1986) and in Canada in Nova Scotia, New Brunswick, and Ontario (Majka \& Klimaszewski, 2008). Adults have been collected from organic debris, fungi near cave entrances, raccoon dung, Neotoma nests (Klimaszewski \& Peck, 1986), compost heaps, forest litter, and decaying gill fungi (Majka \& Klimaszewski, 2008).

Cave ecology: Atheta annexa is one of the most frequent and regular aleocharines in caves in the USA (Peck \& Thayer, 2003). This suggests that it may be able to establish breeding populations underground, though this has not been proven: Klimaszewski \& Peck (1986) imply that it is usually found near cave entrances.

\section{Scarabaeidae}

Agolinus leopardus (Horn, 1870)

NS cave records: Frenchman's Cave, X.1964, D. Calder, d.th. on porcupine dung (1 adult), (Calder \& Bleakney, 1967; D. Calder, pers. comm.); IX-X.1964, D. Calder, th.-d.th. in porcupine dung (six larvae probably this species by virtue of adult occurrence).

Geographical distribution and occurrence: Agolinus leopardus is a Nearctic species, widespread in Canada and the USA, usually found in deer dung.

Cave ecology: Guanophile. Not usually considered a cave species.

\section{Dermestidae}

Dermestes lardarius Linnaeus, 1758

NS cave records: Frenchman's II, 5.X.1997,d.th. on 
wall (1 adult).

Geographical distribution and occurrence: This is a widespread cosmopolitan species, commonly associated with stored food products in anthropogenic situations. The earliest records in North America are from 1670 and in Nova Scotia from 1827 (Majka, 2007).

Cave ecology: Accidental.

\section{Latrididae}

Corticaria serrata (Paykull, 1798)

NS cave records: Minasville Ice Cave, 23.IX.1995, d.th. in dry 'well decomposed' porcupine dung, pH 7.2 (1ㅇ, det. C. G. Majka).

Geographical distribution and occurrence: An adventive European beetle, which is now widespread in Nova Scotia (Majka et al., in press). It is frequently associated with stored products and is found in mouldy plant debris (Majka et al. in press).

Cave ecology: A guanophile. Not known to regularly inhabit caves in Europe (Rücker, 2005).

\section{Curculionidae: Entiminae}

\section{Otiorhynchus ligneus (Olivier, 1807)}

NS cave records: Frenchman's II, 18.X.1997, d.th. in molasses trap set in area of clean damp sand, gravel and pebbles (1 adult, det. C. G. Majka).

Geographical distribution and occurrence: This adventive European root weevil was first recorded in North America in 1917 in New Brunswick (Brown, 1940) and is now found throughout Atlantic Canada and in Maine (Majka et al., 2007).

Cave ecology: This phytophagus weevil is not normally associated with caves, and probably only occurs in such habitats as a seasonal transient.

\section{Barypeithes pellucidus (Boheman, 1834)}

NS cave records: Frenchman's Cave, 28.VII.2007, th. on moss ( 1 adult, det. C. G. Majka): Cheverie Cave, 30.VII.2007, d.th. on rock surface (1 adult, det. C. G. Majka).

Geographical distribution and occurrence: First recorded from the northeastern USA early in the 20th century (Blatchley \& Leng, 1916), this Palaearctic weevil is now widespread throughout much of North America including Nova Scotia (Majka et al., 2007). It was common 2.VII.1998 in litter and damp moss on the surface outside Frenchman's Cave.

Cave ecology: This phytophagus weevil is not normally associated with caves, and is probably a seasonal transient.

\section{Sciaphus asperatus (Bonsdoff, 1785)}

This weevil, recorded by Moseley (2007a) from a cave in Nova Scotia, was reported in error. The record refers to $O$. ligneus.

\section{DISCUSSION}

\section{Overview}

Beetles are infrequently collected in caves and mines in Nova Scotia. With one exception, all recorded species are uncommon to very rare in underground collections and it is also noticeable that few of the records are from dark zone situations. The prominent exception is the native Nearctic rove-beetle $Q$. $s$. spelaeus. Half of the beetles collected in the period 1969-2007 were this species. Although based on purely qualitative collecting, there is little doubt that this reflects a genuine scarcity of these insects at such sites: most beetles are relatively conspicuous and easily-collected in caves, and thus collecting bias ought to lead to their over-representation rather than under-representation.

The cave-associated coleopteran fauna of Nova Scotia is also impoverished taxonomically. The most speciose family Staphylinidae is represented by four of a total fifteen taxa. Three dytiscids and two curculionids are also represented with the balance being from six miscellaneous families. There are no records of carabids. Five of the terrestrial beetles are adventive Palaearctic species. All the staphylinids are native, whereas only three of the remaining seven terrestrial beetles (A. leopardus, A. castanea, and $C$. gratiosus) are Nearctic species. Thus, if only native North American beetles are considered, the preponderance of staphylinid species $4 / 7$ terrestrial beetles) is striking.

There are no anopthalmic troglomorphs although $Q$. s. spelaeus is primarily subterranean and the Nova Scotia population probably exclusively so. A small suite of guanophiles are associated with accumulations of porcupine dung that constitute a major energy source in Nova Scotia caves (Moseley, 2007a): A. castanea, Q. s. spelaeus, A. leopardus and $C$. serrata. Two of the rove-beetles, G. canadensis and A. annexa, together with $C$. gratiosus, constitute a small group of cave-associated beetles commonly found in decompositional situations. An omaliine, B. nitidus, is a Nova Scotia representative of a fairly large suite of cave-associated staphylinids that, on the surface, are usually found in moist habitats near water (Assing, 2007). Two adventive weevils, O. ligneus and B. pellucidus, collected in shallow cave passages, are probably seasonal transients while the remaining species, $D$. lardarius, recorded from one cave, was probably an accidental (stray).

Aquatic beetles are rarely collected. Of the four recorded taxa only A. larsoni is likely to be habitual in caves in this region: records of two other predaceous diving beetles (A. sp. prob. semivittatus and Dytiscus sp.) and C. digesta, a scavenger, are considered to represent accidentals (strays).

\section{Predaceous terrestrial beetles}

The distribution pattern of predaceous terrestrial beetles in Nova Scotia cave communities is unusual and difficult to explain. It is characterized by very low species diversity (4 species) and is restricted to a single family, the Staphylinidae. There are no trechines or other carabids. Within the Staphylinidae there is only one relatively frequently collected species (Q. s. spelaeus) with other cavernicolous rove 
beetles that are known to be present in the province being uncommon, rare, or absent in underground collections.

The absence of species of Carabidae is puzzling. Throughout much of the world this family occupies the niche of dominant predatory cave beetles (Peck \& Thayer, 2003) and is also represented in most cave guano communities (Gnaspini \& Trajano, 2000). Together with the Leiodidae, the Carabidae (especially Trechinae) constitutes more than 90\% of known 'troglobitic' Coleoptera (Gibert \& Deharveng, 2002; Moldova \& Rajka, 2007).

Although the very large family Staphylinidae with more than fifty thousand described species is only represented in cave communities worldwide by a handful of 'troglobites', and relatively few other cavernicolous species (Gibert \& Deharveng, 2002; Peck \& Thayer, 2003; Hlavac et al., 2006), this does not reflect the ecological significance of rove-beetles in subterranean habitats. Those few species that have established populations in caves are commonly present and frequently-collected, especially in North America (Peck \& Thayer, 2003).

Peck \& Thayer (2003) listed 67 species of staphylinid beetles (excluding Aleocharinae and Pselaphinae) from caves in the continental United States, of which 9 are 'frequently occurring'. Klimaszewski \& Peck (1986) recorded 20 species of aleocharines from caves in eastern North America, including 6 'frequently occurring' species, whilst Chandler (1997) recorded 43 species of pselaphines from caves on the continent.

Most of those species found in caves are nontroglomorphic forms that have well-developed eyes and are capable of flight. The majority are thought to be species that are either associated with rotting organic matter, or alternatively with moist habitats near water (Assing, 2007) and those recorded from caves in Nova Scotia fit this pattern.

The observed low diversity of predaceous caveassociated Coleoptera in Nova Scotia reflects in part the well-documented relative impoverishment of the provincial invertebrate fauna in comparison with that of neighbouring regions of northeastern North America. However there are a number of species that are widespread in surface habitats in Nova Scotia yet have never been found in caves there despite being often present in subterranean habitats elsewhere. The absence of carabids (including species of genera such as Agonum, Bembidion and Trechus that commonly have cave-associated representatives in other geographical regions) has already been mentioned. Three staphylinids, Lesteva pallipes LeConte, Quedius mesomelinus (Marsham) and Quedius curtipennis Bernhauer, are other examples of Nova Scotia species that occur in caves elsewhere, but have not been found in subterranean habitats in Nova Scotia.

Quedius mesomelinus is a compelling example. This Palaearctic species was an early anthropogenic introduction to North America being found in archaeological deposits dating from the $17^{\text {th }}$ century (Prévost \& Bain, 2006) and it is now widespread in Nova Scotia and elsewhere in eastern North America
(Majka \& Smetana, 2007). It is one of the species frequently collected in caves in the eastern USA (Peck $\&$ Thayer, 2003), and there are cave records from the northern part of its range in Ontario (Peck, 1988) and New Brunswick (Moseley, 2007a). In Europe it is common and widespread in caves (Smetana, 1971). However, this conspicuous beetle has never been collected underground in Nova Scotia and it is probably either extremely rare or entirely absent from caves there.

The Nearctic species Lesteva pallipes is widespread in eastern Canada, including Nova Scotia, and in the eastern and central USA where it is another of the staphylinids 'frequently occurring' in caves (Peck \& Thayer, 2003).

Quedius curtipennis is another introduced European species. The earliest North American records are from 1934 in Seattle (Smetana, 1971) and the species is established in Nova Scotia (Majka \& Smetana, 2007). It is occasional in caves in Europe but apparently not in Nova Scotia, although a single pupa found in moss outside the entrance of Woodville Ice Cave (5.VIII.2007) shows that it occurs in habitats in the immediate vicinity of caves.

Although it is possible that $Q$. curtipennis, L. pallipes or other infrequently-collected beetles will turn up in Nova Scotia caves, they are certainly scarce and the preponderance of $Q$. s. spelaeus in underground collections, the rarity (especially in cave dark zones) of other recorded staphylinids, and the general absence of other species including, tellingly, the common and vigorous $Q$. mesomelinus and all carabids, all point to the former species as the almost exclusive occupant of the niche of predatory beetle in provincial caves. This can be seen as a rather extreme instance of the pattern elsewhere in North America where although introduced troglophilic rove-beetles including $Q$. mesomelinus have occupied and become established in niche spaces in American caves, they have not displaced native species (Peck \& Thayer, 2003).

The failure of most coleopteran predators to become established contrasts with the pattern observed in other terrestrial invertebrates many of which appear to have met few ecological or competitive barriers in colonizing caves in Nova Scotia. It is speculated that these species occupied empty niches that existed because subterranean ecosystems in the region are at a very early stage of repopulation following the Pleistocene (Moseley, 2007a). It appears that, in contrast, the native $Q$. s. spelaeus has been able to competitively exclude other native and invasive predatory beetles from this habitat.

The ecological success of Quedius s. spelaeus is probably due to relatively advanced adaptation to this environment. Several authors have made the plausible argument that highly-adapted cave species may be able to defend their subterranean niche from subsequent colonists (White et al., 2009).

Quedius spelaeus is a somewhat distinct species that differs from other members of the large sub-genus Microsaurus by the explanate pronotum, impunctate scutellum and a strongly asymmetrical male copulatory 
organ (Smetana, 1971). The relationships between these species-specific morphological features and its mode of life are unclear. However the pale colouration observed in most populations is due to absence of pigmentation other than the underlying amber colour of chitin: unlike many other organisms cave-beetles are never white and the colour of $Q$. spelaeus matches that of highly adapted troglomorphic Coleoptera. Behaviours such as the excavation of occupation cells by larvae (Moseley et al., 2006) may be associated with living in darkness: Turquin (1983) found that in the absence of other shelter cave-dwelling Quedius mesomelinus builds burrows in clay substrate.

\section{Leiodidae: Cholevinae}

The new cave records of $C$. gratiosus are of interest. Leiodidae and especially the subfamily Cholevinae are one of the two most speciose groups of 'troglobitic' beetles (Gibert \& Deharveng, 2002; Moldova \& Rajka, 2007). Of the more than 80 species of Cholevinae found in North America (Peck \& Cook, 2007) several are variously associated with caves including a number that are anopthalmic troglomorphs (e.g. Ptomaphagus spp. in the southeastern USA) (Peck,1973, 1984). Although it has no obvious morphological adaptations for cave life $C$. gratiosus is frequently though not exclusively found in caves (usually near the entrances) in the southeastern USA and has also been found in caves in Ontario in eastern Canada (Peck, 1988) and now in Nova Scotia. Surface collections in western North America and the northeastern USA and Canada are from various decomposition situations in forested environments, whilst in caves they have been found on dead mice and bats (Peck \& Cook, 2007).

Another leiodid, Prionochaeta opaca (Say), is a further example of a beetle that is unexpectedly absent from Nova Scotia cave collections. Its distribution and ecology are similar to those of $C$. gratiosus. It is a widely distributed North American species primarily found associated with carrion in forested environments but also found on bat guano in caves in the southeastern United States (Peck 1977). Peck (1977) and Peck \& Cook (2002) reported records from 52 caves in 12 states in the southeastern United States west to Arkansas, Oklahoma, Missouri, and Iowa, and it is also present in caves in the northern part of its range in Ontario (Peck, 1988). It has been recorded from epigean habitats in New Brunswick, Prince Edward Island, and Nova Scotia (Majka \& Langor, 2008) but not from caves.

\section{Guanophiles}

Four beetles A. castanea, Q. s. spelaeus, A. leopardus, and $C$. serrata constitute a small suite of species associated with the extensive deposits of porcupine dung that constitute a major food source in Nova Scotia caves (Moseley, 2007a).

The historical view that animals inhabiting guano in caves are 'false cave-dwellers' (Ruffo, 1957; Vandel, 1964) has been challenged by some recent authors who have advanced arguments that all animals regularly found in such habitats underground should be considered bona fide cavernicoles (Gnaspini, 1992; Moseley, 2007a). In this context it can be argued that Q. s. spelaeus is an instructive example that provides addition evidence in support of this view. This beetle is almost exclusively subterranean, yet it is primarily a predator exploiting and restricted to animal dung and other high-energy environments. The guano habitat in caves is presumably a route by which some organisms first colonize subterranean environments

\section{Woodville Ice Cave}

Finally, mention needs to be made of the diversity of beetles found in Woodville Ice Cave. Four species have been recorded, all cavernicolous to a greater or lesser extent: three staphylinids ( $Q$. s. spelaeus, A. annexa, and $G$. canadensis) and C. gratiosus. Although the site is a small shallow cave with no significant accessible dark zone (Figs. 5, 6), it contains a uniquely diverse and hence notable cave-associated coleopteran fauna in

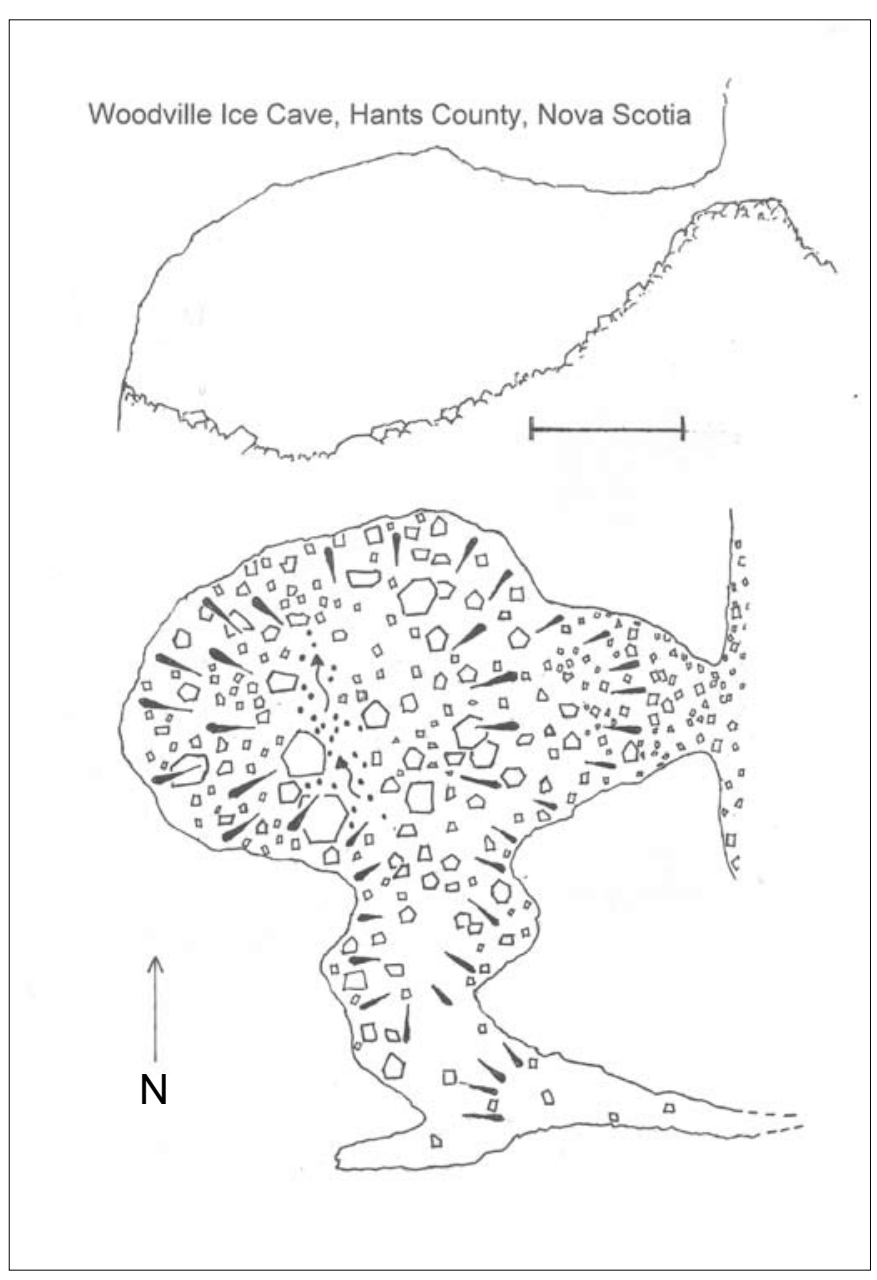

Fig. 5. Woodville Ice Cave, map and projected elevation. Scale line $=5 \mathrm{~m}$

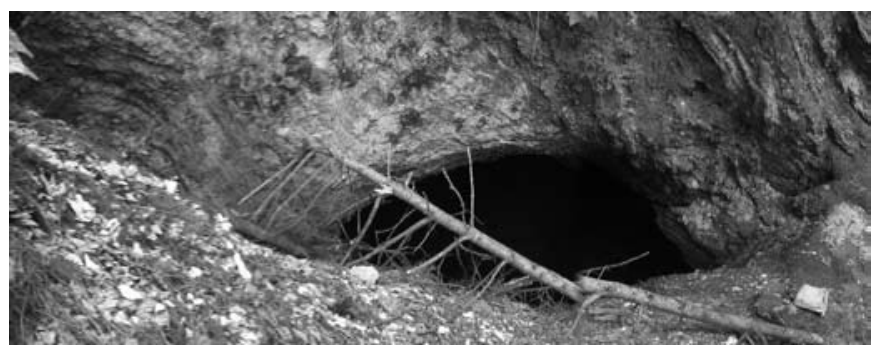

Fig. 6: Entrance of Woodville Ice Cave, Hants County, Nova Scotia (photo: author). 
Nova Scotia. The accessible cave is comprised primarily of a deep threshold environment with only a small area of dark zone in a side passage. Ice regularly persists in the cave chamber until early August. Air temperature just above the floor at this time can be $2.5^{\circ} \mathrm{C}$ while the temperature within the large, deep talus pile that almost seals the entrance is $<0.5^{\circ} \mathrm{C}$ (Moseley, 2007b). All species were taken in pitfall traps sited near leaf litter on the talus inside the cave entrance: a deep threshold area in cool air below the thermocline which forms during the summer months. The beetles and other cavernicolous invertebrates found here are believed to represent a sample of the subterranean fauna inhabiting deep cavities within the talus. This is an environment comparable with European Alpine Kaltlöcher and similar sites where cavernicolous and psychro-hydrophilous organisms are found associated with stable, cold habitats in cavities in scree or solid rock (e.g. Core, 1968; Růžička et al., 1995; Punz et al., 2005).

\section{Conservation implications}

None of the cave-associated beetles recorded in Nova Scotia are believed to be under threat. The only caverestricted species, Q. s. spelaeus, occurs at all or almost all sites and the remaining species, though rarely collected underground, are widespread in epigean habitats. However, the preservation and protection of caves and abandoned mines that support representative populations of these beetles and characteristic species and communities of other organisms is important. Woodville Ice Cave is a provincially significant site, and is especially deserving of protection.

\section{ACKNOWLEDGEMENTS}

I thank my colleagues among the staff and Research Associates of the Nova Scotia Museum (NSMNH), especially C. G. Majka who identified several key specimens and gave freely of his extensive knowledge of the distribution of the beetles of Atlantic Canada. Jan Klimaszewski (Canada) kindly determined Atheta annexa and A. E. Davis (Canada) sent details of specimens held in the National Collection of Insects, Arachnids and Nematodes. Several excellent photographs are the work of G. Pelletier (Canada), and the location map was generated from the NSMNH database. Valuable comments were also provided by L. Latella (Italy) and the two anonymous reviewers. Finally, the Board of Governors of NSMNH is gratefully thanked for research grants in partial support of fieldwork.

\section{REFERENCES}

Assing V., 2007 - A new genus and species of Aleocharinae from a cave in Georgia (Coleoptera: Staphylinidae). Linzer biologische Beiträger, 39(1): 33-38.

Blatchley W. S. \& Leng C. W., 1916 - Rhynchophora or weevils of North Eastern America. The Nature Publishing Co., Indianapolis, Indiana. $682 \mathrm{p}$.

Brown W. J., 1940 - Notes on the American distribution of some species of Coleoptera common to the European and North American continents. The Canadian Entomologist, 72: $65-78$.
Calder D. R. \& Bleakney J. S., 1967 - Observations on Frenchman's Cave, Nova Scotia, and Its Fauna. Bulletin of the National Speleological Society, 29(1): 23-25.

Chandler D.S., 1997 - A Catalogue of the Coleoptera of America North of Mexico: Pselaphidae. United States Department of Agriculture Handbook 529-31. 118 p.

Core E. L., 1968 - The Botany of Ice Mountain, West Virginia. Castanea, 33: 345-348.

Gibert J. \& Deharveng L., 2002 - Subterranean ecosystems: a truncated functional biodiversity. BioScience, 52: 473-481.

Gnaspini P., 1992 - Bat guano ecosystems. A new classification and some considerations, with special reference to Neotropical data. Memoires Biospéléologie, 19: 135-138.

Gnaspini P. \& Trajano E., 2000 - Guano Communities in Tropical Caves. In: (H. Wilkens, H., D. C. Culver and W. F. Humphreys, editors) Ecosystems of the World: Vol. 30, Subterranean Biota. Elsevier, Amsterdam: 251-268.

Hlavac P., Oroni P. \& Bordoni A., 2006 - Catalogue of troglobitic Staphylinidae (Pselaphinae excluded) of the world. Subterranean Biology, 4: 19-28.

Klimaszewski J. \& Peck S. B., 1986 - A review of the cavernicolous Staphylinidae (Coleoptera) of Eastern North America: Part 1. Aleocharinae. Quaestiones Entomologicae, 22: 51-113.

Larson D. J., Alarie Y. \& Roughley R. E., 2000 Predaceous Diving Beetles (Coleoptera: Dytiscidae) of the Neartic Region, with emphasis on the fauna of Canada and Alaska. NRC Research Press, Ottawa, Ontario, Canada. 982 p.

Majka C. G., 2007 - The Derodontidae, Dermestidae, Bostrichidae, and Anobiidae of the Maritime Provinces of Canada (Coleoptera: Bostrichiformia). Zootaxa, 1573: $1-38$.

Majka C. G., Anderson R. S. \& McCorquodale D. B., 2007 - The weevils (Coleoptera: Curculionoidea) of the Maritime Provinces of Canada, II: New records from Nova Scotia and Prince Edward Island and regional zoogeography. The Canadian Entomologist, 139:397442.

Majka C. G. \& Klimaszewski J., 2008 - New Records of Canadian Aleocharinae (Coleoptera: Staphylinidae). In: (C. G. Majka \& J. Klimaszewski, editors) Biodiversity, Biosystematics and Ecology of Canadian Coleoptera. ZooKeys, 2: 85-114.

Majka C. G. \& Langor D., 2008 - The Leiodidae (Coleoptera) of Atlantic Canada: new records, faunal composition and zoogeography. In: (C.G. Majka \& J. Klimaszewski, editors) Biodiversity, Biosystematics, and Ecology of Canadian Coleoptera. ZooKeys, 2: 357-402.

Majka C.G., Langor D. \& Rücker W., in press - The Latrididae of Atlantic Canada: new records, keys, distribution, and zoogeography. The Canadian Entomologist.

Majka C. G., Moseley M. \& Klimaszewski J., 2006 - Gennadota canadensis (Casey) (Staphylinidae: Aleocharinae): new records, a range extension, and bionomic notes. The Coleopterists Bulletin, 60(3): 231-234. 
Majka C. J. \& Smetana A., 2007 - New Records of introduced species of Quedius Stephens, 1829 (Coleoptera: Staphylinidae) from the Maritime Provinces of Canada. Proceedings of the Entomological Society of Washington, 109(2): 427-434.

Majka C. J. \& Sörensson M., 2007 - Ptilidae of the Maritime Provinces of Canada (Coleoptera): new records and bionomic notes. Zootaxa, 1423: 27-38.

Moldova O. T. \& Rajka G., 2007 - Historical Biogeography of Subterranean Beetles - "Plato's Cave" or Scientific Evidence? Acta Carsologica, 36(1): 77-86.

Moseley M., 1998 - Invertebrate Fauna of Nova Scotia Caves. Nova Scotia Museum Curatorial Report, 86: 1-40.

Moseley M., 2007a-Acadian biospeleology: composition and ecology of cave fauna of Nova Scotia and southern New Brunswick, Canada. International Journal of Speleology, 36(1): 1-18.

Moseley M., 2007b - Woodville Ice Cave (Hants County, Nova Scotia) and notes on the 'ice caves' of the Maritime Provinces. Proceedings of the Nova Scotia Institute of Science, 44(1): 73-78.

Moseley M., Klimaszewski J. \& Majka C. J., 2006 - Description of the pupa and observations on the distribution, ecology and life history of Quedius spelaeus spelaeus Horn (Coleoptera: Staphylinidae) in Nova Scotia, Canada. Zootaxa, 1226: 61-68.

Peck S. B., 1973 - A systematic revision and the evolutionary biology of the Ptomaphagus (Adelops) beetles of North America (Coleoptera: Leiodidae: Catopinae) with emphasis on cave-inhabiting species. Bulletin of the Museum of Comparative Zoology, 145: 29-162.

Peck S. B., 1975 - A Review of the Distribution and Habitats of North American Brathinus (Coleoptera: Staphylinidae: Omaliinae). Psyche, 82: 59-66.

Peck S. B., 1977 - A review of the distribution and biology of the small carrion beetle Prionochaeta opaca of North America (Coleoptera: Leiodidae: Catopinae) Psyche, 83: 299-307.

Peck S. B., 1984 - The distribution and evolution of cavernicolous Ptomaphagus beetles in southeastern United States (Coleoptera: Leiodidae: Cholevinae) with new species and records. Canadian Journal of Zoology, 62: 730-740.

Peck S. B., 1988 - A review of the cave fauna of Canada, and the composition and ecology of the invertebrate fauna of caves and mines in Ontario. Canadian Journal of Zoology, 66: 1197-1213.

Peck S.B. \& Cook J., 2002 - Systematics, distributions, and bionomics of the small carrion beetles (Coleoptera: Leiodidae: Cholevinae: Cholevini) of North America. The Canadian Entomologist, 134: 723-787.
Peck S. B. \& Thayer M. K., 2003 - The Cave-inhabiting rove beetles of the United States (Coleoptera: Staphylinidae; excluding Aleocharinae and Pselaphinae). Diversity and Distribution. Journal of Cave and Karst Studies, 65(1): 3-8.

Prévost M.-A. \& Bain A., 2007 - L'implantation d'une colonie terre-neuvienne au XVIIe siècle:l'apport des analyses archéobotanique et archéoentomologique. In: (A. Bain, J. Chabot, \& M. Moussette, editors) La mesure du passé: contributions à la recherche en archéométrie (2000-2006). Oxford, England: British Archaeological Reports, Archaeopress: 205-216.

Punz W., Sieghardt H., Maier R., Engenhart M. \& Christian E., 2005 - Kaltlöcher im Ostalpenraum. Verhandlungen der Zoologisch-Botanischen Gesellschaft in Österreich, 142: 27-45.

Rücker W., 2005 - Geographische Formen der Aedoeagi bei Corticaria serrata (Paykull, 1798). Mitteilungsblatt für Systematik und Taxonomie der Latrididae, 3: 9-10.

Ruffo S., 1957 - Le attuali conoscenze sulla fauna cavernicola della Regione Pugliese. Memorie di Biogeografica Adriatica, 3: 1-143.

Rusdea E., 1994 - Population dynamics of Laemostenus schreibersi (Carabidae) in a cave in Carinthia (Austria). In: K. Desender et al (eds.) Carabid Beetles: Ecology and Evolution, Kluwer Academic Publishers: 207-212.

Růžička V., Hajer J. \& Zacharda M., 1995 - Arachnid population patterns in underground cavities of a stony debris field (Aranea, Opliliones, Pseudoscorpionidae, Acari: Prostigmata, Rhagidiidae). Pedobiologia, 39: 42-51.

Smetana A., 1971 - Revision of the tribe Quediini of America north of Mexico (Coleoptera: Staphylinidae). Memoirs of the Entomological Society of Canada, 79: 1-303.

Sörensson M., 2003 - New records of Featherwing Beetles (Coleoptera: Ptilidae) in North America. The Coleopterists Bulletin, 57: 369-381.

Turquin M.-J., 1983 - The place of Quedius mesomelinus (Staphylinidae) in the cavernicolous ecosystem. Mémoires de Biospéologiques, 10: 153158.

Vandel A., 1964 - Biospéologie. La Biologie des Animaux Cavernicoles. Paris: Gauthier-Villars. 619 p.

White K., Davidson G. R. \& Paquin P., 2009 Hydrologic evolution of the Edwards Aquifer recharge zone (Balcones fault zone) as recorded in the DNA of eyeless Circurina cave spiders, south-central Texas. Geology, 37(4): 339-342. 